\title{
Localised prostate cancer treated with MRI- guided transurethral ultrasound ablation: phase I trial results
}

\author{
MB Wolf ${ }^{*}$, M Roethke 1 S Pahernik², B Hadaschik², T Kuru², IV Popeneciu², G Hatiboglu², J Chin ${ }^{3}$, M Billia ${ }^{3}$, J Relle ${ }^{4}$, \\ J Hafron ${ }^{4}$, K Nandalur $^{4}$, M Burtnyk ${ }^{5}$, HP Schlemmer ${ }^{1}$
}

From International Cancer Imaging Society (ICIS) 14th Annual Teaching Course

Heidelberg, Germany. 9-11 October 2014

\section{Purpose}

Purpose of this prospective, multi-institutional Phase I clinical study was to investigate whether MRI-guided transurethral ultrasound ablation (MR-TULSA), a novel minimally-invasive technology to treat organ-confined prostate cancer $(\mathrm{PCa})$, is safe, feasible and effective. It employs directional plane-wave high-intensity ultrasound, which ablates prostate tissue using real-time thermometry with active temperature feedback control.

\section{Methods}

Enrolled were 30 patients with biopsy-proven, low-risk prostate cancer (age $\geq 65 \mathrm{y}, \mathrm{T} 1 \mathrm{c} / \mathrm{T} 2 \mathrm{a}, \mathrm{PSA} \leq 10 \mathrm{ng} / \mathrm{ml}$, Gleason $6(3+3))$. Whole-gland prostate ablation was performed with MR-TULSA using the PAD-105 (Profound Medical Inc., Canada) and a 3T MRI (Siemens, Germany) in one single treatment session under general anaesthesia and 3D active MR-thermometry feedback control. Contrast-enhanced MRI (CE-MRI) immediately following the ablation and at 12 months confirmed thermal coagulation.

\section{Results}

There were no intraoperative complications with normal micturition resuming after catheter removal. Median (range) treatment time and prostate volume were 36 (24-61) min and 44 (21- 95) $\mathrm{ml}$, respectively. Maximum temperature during treatment depicted a continuous region of heating shaped accurately to the prostate within $0.1 \pm 1.3 \mathrm{~mm}$, with average over- and under-targeted volumes of 0.8 and $1.0 \mathrm{ml}$, respectively. Regions of acute cell kill on CE-MRI correlated well with treated volume on MR-thermometry. Successful treatment was further confirmed by a median PSA decrease from 5.35 to 0.70 $\mathrm{ng} / \mathrm{ml}$ at 1 month $(\mathrm{n}=29)$, remaining stable to $0.65 \mathrm{ng} / \mathrm{ml}$ at 6 months $(\mathrm{n}=16)$.

\section{Conclusion}

Phase I results show that MR-TULSA represents a minimally-invasive treatment option for safe, effective and accurate whole-gland thermal ablation of organ-confined prostate cancer.

\section{Authors' details}

'Radiology, German Cancer Research Center (DKFZ), Heidelberg, Germany. ${ }^{2}$ Urology, University Hospital, Heidelberg, Germany. ${ }^{3}$ Urology, Western University (UWO), London Health Sciences Center, Victoria Hospital, London ON, Canada. ${ }^{4}$ Urology and Radiology, Beaumont Health System, Royal Oak MI, USA. ${ }^{5}$ Profound Medical Inc., Toronto ON, Canada.

Published: 9 October 2014

doi:10.1186/1470-7330-14-S1-S3

Cite this article as: Wolf et al:: Localised prostate cancer treated with MRI-guided transurethral ultrasound ablation: phase I trial results. Cancer Imaging 2014 14(Suppl 1):S3.

\footnotetext{
* Correspondence: m.mueller-wolf@dkfz.de

'Radiology, German Cancer Research Center (DKFZ), Heidelberg, Germany

Full list of author information is available at the end of the article
} 